\title{
Wet flue gas desulphurisation procedures and relevant solvents thermophysical properties determination
}

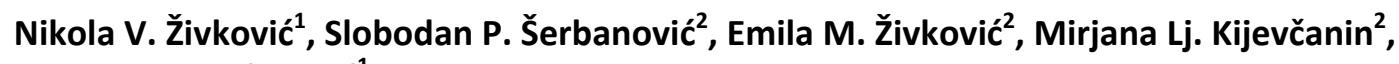 \\ Predrag Lj. Stefanović ${ }^{1}$ \\ ${ }^{1}$ Institute for Nuclear Sciences "Vinča", University of Belgrade, Laboratory for Thermal Engineering and Energy, P.O. \\ Box 522, 11001 Belgrade, Serbia \\ ${ }^{2}$ Faculty for Technology and Metallurgy, University of Belgrade, Karnegijeva 4, 11120 Belgrade, Serbia
}

\begin{abstract}
In order to mitigate climate change, the priority task is to reduce emissions of greenhouse gases, including sulfur oxides, from stationary power plants. The legal framework of the European Union has limited the allowable emissions of gases with harmful effects and fulfillment of this obligation is also ahead of the Republic of Serbia in the following years. In this paper the categorization of wet procedures for sulfur oxides removal is given. Wet procedure with the most widespread industrial application, lime/limestone process, has been described in detail. In addition, the procedures with chemical and physical absorption and solvent thermal regeneration, which recently gained more importance, have been presented. Experimentally determined thermophysical and transport properties of commercially used and alternative solvents, necessary for the equipment design and process optimization, are also given in the paper. The obtained values of densities and viscosities of pure chemicals - solvents, polyethylene glycol 200 (PEG 200), polyethylene glycol 400 (PEG 400), tetraethylene glycol dimethyl ether (TEGDMA), N-methyl-2-pyrolidon (NMP) and dimethylaniline (DMA), measured at the atmospheric pressure, are presented as a function of temperature.
\end{abstract}

Keywords: removal of sulfur oxides, flue gases, thermal power plant, density, viscosity, climate change.

SCIENTIFIC PAPER

UDC 621.311.22:628.53:502.3:504.5

Hem. Ind. 68 (0) 491-500 (2014)

doi: 10.2298/HEMIND130610074Z

Available online at the Journal website: http://www.ache.org.rs/HI/

The sulfur oxides, generated by combustion of fuels containing sulfur (coal, oil), are the greenhouse gases with indirect effect. It is well known that these gases have a harmful impact on the environment, causing the occurrence of acid rains and respiratory problems. The flue gas desulphurization (FGD) processes had no commercial application, until the importance to protect the environment was understood, and consequently, the national legal regulations were adopted [1,2].

The EU regulations limited emissions of greenhouse gases and developed strategies to adapt to climate change. Republic of Serbia is facing a number of obligations, including the reduction of emissions of greenhouse gases, in the process of joining the European Union. Having this in mind, the processes used for flue gas desulphurization gained its importance.

This paper gives an overview of wet processes used for the removal of sulfur oxides from stationary power plants. Wet processes can be classified in non-regenerative (once-through) and regenerative procedures. The most important among them and also the most

Correspondence: E.M. Živković, Faculty for Technology and Metallurgy, University of Belgrade, Karnegijeva 4, 11120 Belgrade, Serbia.

E-mail: emila@tmf.bg.ac.rs

Paper received: 10 June, 2013

Paper accepted: 12 July, 2013 common in general practice is non-regenerative lime/ /limestone process. In this process the alkaline mixture is a reagent and gypsum is a final product. In regenerative procedures, used solvent is thermally regenerated and circulated back to the process. Among the regenerative procedures the most widespread are dual alkali process, process of chemical absorption in amines and process of physical absorption in organic solvents. The regenerative processes are further divided into those whose final product is disposed on landfill, and those with a commercially useful product.

For computer simulations, equipment design and consequently implementation of FGD procedures, it is necessary to have reliable data on thermophysical and transport properties of potential solvents. This paper presents experimentally determined densities $(\rho)$ and viscosities $(\eta)$ of pure solvents, polyethyleneglycol 200 (PEG 200), polyethyleneglycol 400 (PEG 400), tetraethylene glycol dimethyl ether (TEGDME), $N$-methyl-2-pyrollidone (NMP) and dimethylaniline (DMA), in the temperature range from 288.15 to $323.15 \mathrm{~K}$ and at atmospheric pressure. Some of the above mentioned liquids have already found industrial application in the regenerative processes with organic solvents, while the others are suggested as alternative absorbents due to 
their favourable environmental impact, low toxicity or suitable physical and chemical properties.

\section{Wet FGD processes}

As stated above wet FGD processes can be classified into regenerative and once-through. Unlike once-through procedures, the regenerative processes include solvent regeneration stage. Based on the records of flue gases desulphurization processes on thermal power plants in the US, about 90\% [3] of the applied procedures are once-through. Wet lime/limestone process has been used in about 78\% [3] of plants in the US, and still is the most widespread FGD technology, with gypsum as the final, commercially valuable byproduct.

A general flow diagram of the non-regenerative FGD process is shown in Figure 1. The main part of the unit is the absorber, where the flue gas containing $\mathrm{SO}_{2}$ is brought to contact with alkaline slurry. Before alkaline slurry enters the absorber, the sorbent solid particles are crushed (at desired particle size) in a crushing station. This is inevitable step, since crushing of the solid particles will increase dissolution rate in the preparation tank. The alkaline slurry is then fed to the reaction tank and transported to the top of the absorber, usually constructed as a spray tower or tray tower. The most common configuration of the absorber is vertical with counterflow of the phases, where the flue gas containing $\mathrm{SO}_{2}$ is flowing upwards, and set of nozzles spray alkaline slurry (lime/limestone) downwards. In the process of removing $\mathrm{SO}_{2}$, two mechanisms take place, the sorption in the absorber and chemical reaction with the alkaline slurry in the reaction tank.

\section{Lime/limestone process}

Lime/limestone is by far the most common FGD process. The method was patented by Eschellman in 1909. The first commercial application of lime process was in London, England, and the first unit of the Battersea Power Station was put into operation in 1931. This once-through process used small amount of chalk added to water from River Thames as solvent. Many modern and improved lime/limestone processes $[3,4]$ were based on this process.

Babcock \& Wilcox Power Generation Group developed wet flue gas desulfurization systems based on standard lime/limestone process [5]. The reagent is an alkaline mixture of lime (calcium oxide $(\mathrm{CaO})$ and calcium hydroxide $\left(\mathrm{Ca}(\mathrm{OH})_{2}\right)$ ) or limestone (calcium carbonate $\left.\left(\mathrm{CaCO}_{3}\right)\right)$ in water. The alkaline mixture as a reagent is introduced in absorber and brought into contact with flue gases containing $\mathrm{SO}_{2}$. Insoluble sulfates and sulfites $\left(\mathrm{CaSO}_{4}\right.$ and $\mathrm{CaSO}_{3}$ ) formed in the reaction are removed as sludge. Gas, purified after passing through the separator, is released to the atmosphere. Used sludge from absorber is sent to the reaction tank, then to a dewatering stage where water is removed and finally to the landfill. The chemical reactions and process equipment are very similar regardless of whether the alkaline mixture of water with lime or limestone is used. Schematic representation of wet lime/limestone is similar to the general flow diagram presented in Figure 1.

For some applications, and under particular operating conditions, it is allowed to leave sulfite to sulfate oxidation process intact, in so-called natural oxidation mode. For most applications, however, it is necessary

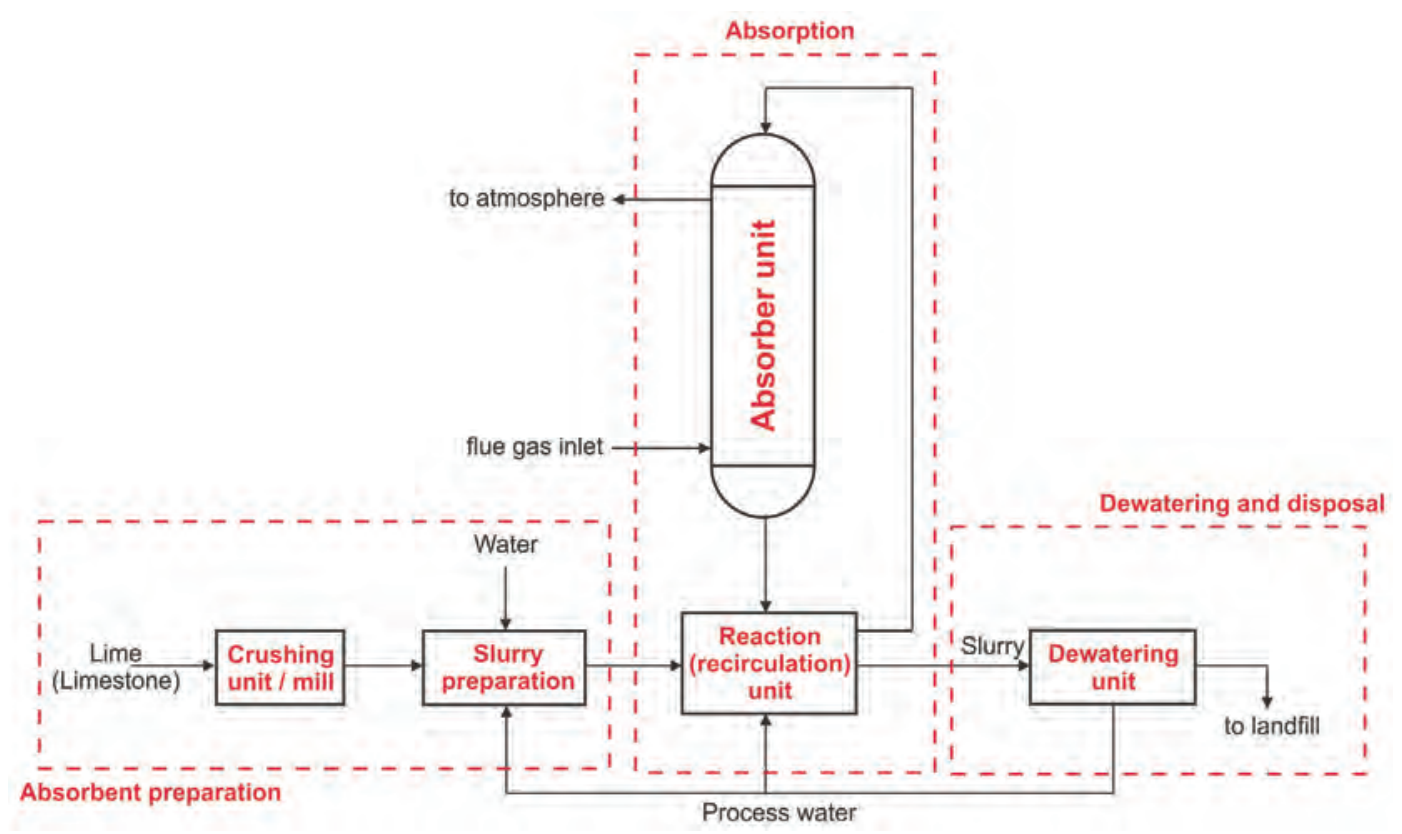

Figure 1. Wet FDG process - general flow diagram. 
to control the oxidation process. One of the parameters that affects the process of oxidation in the absorber is liquid to gas phase flow rate ratio (L/G). Slurry $\mathrm{pH}$ is another process parameter that determines the amount of $\mathrm{SO}_{2}$ removed. In order to improve reliability of the process it is necessary to control the oxidation process, so the limestone forced oxidation (LSFO) is most widespread subvariant. In order to prevent scaling problems, deposition of calcium sulfate gypsum in the absorber, mist eliminator and piping, and to simplify slurry dewatering, air is usually blown through the absorbent slurry to force controlled oxidation outside the absorber. The air have to be blown through the reaction tank (in-situ oxidation) or through additional hold tank (ex-situ oxidation). Since market demand for gypsum has been reduced over the years and a wastewater treatment became a requirement, FGD technology with inhibited oxidation (LSIO) was offered as a solution.

In order to avoid scaling problems, sulfur and sodium thiosulfate emulsion could be added to the reaction tank, thus reducing oxidation rate below $15 \%$. This variant of the process can be used with various reagents, lime, limestone, magnesium-enhanced lime and sodium. The advantages of LSIO are low investment and reagent costs and no necessity for wastewater treatement, which lead to lower overall operational costs.

Another sub-variety of lime/limestone procedure is a process enhanced by the presence of magnesium. As a sorbent, lime sludge is used, which is a mixture of water, lime and 5-8\% magnesium oxide, or a mixture of water, lime and dolomite lime (with about $20 \%$ magnesium oxide). The enhanced process is very efficient compared to classic procedure and the final product is high-quality gypsum.

Since limestone is less reactive than lime, it requires slightly modified process equipment. The advantage of limestone compared to lime is in its market value (about 3 times cheaper than lime) which makes it more acceptable for use in large systems.

Wet lime/limestone process parameters are: flue gas velocity (residence time) through the absorber, L/G ratio, lime/limestone milk $\mathrm{pH}$ value, $\mathrm{SO}_{x}$ concentration and solid particles concentration. Flue gas velocity through the absorber depends on the type of absorber. For absorber with countercurrent flow, increasing the speed of the flue gases, can lead to lower $\mathrm{SO}_{2}$ removal efficiency. Required alkalinity of the process rises with the increase of $L / G$ ratio. Efficiency of the process is influenced by $\mathrm{pH}$ value, while the concentration of particles and their residence time in the tank affect the reliability of the process. Typical values of concentration of solids in the mixture are $10-15 \%$ by weight, while the residence time of solids in the tank is $12-14 \mathrm{~h}$. Higher values of these parameters can lead to unwanted particles' deposition in the equipment.

Removal efficiency for standard wet lime/limestone process is in range from about 60 to $97 \%$, while for subvariety of enhanced lime/limestone process with magnesium, $\mathrm{SO}_{2}$ removal efficency can be increased to 99\%. Basic operational parameters for lime/limestone systems on utility boilers in United States are given in Table 1.

\section{Dual alkali process}

Process name is derived due to presence of two types of components during absorption. Dual alkali process uses alkaline solution based on sodium as sorbent. Process also includes a stage of sorbent regeneration in which limestone is used. Calcium sulfite and sulfate formed in this stage are separated as sludge, while the regenerated sodium solution is reused in the absorption step (Figure 2). The chemistry of the process is very similar to the lime/limestone process.

Sodium-based solution ( $\mathrm{NaOH}, \mathrm{Na}_{2} \mathrm{CO}_{3}$ and $\mathrm{Na}_{2} \mathrm{SO}_{3}$ ) is brought into contact with the flue gas in the absorber. The used liquid solution is transported to the reactor within regeneration step, where the mixing with limestone, formation of calcium salts and sorbent regeneration take place. The sludge from the reactor is directed to the clarifier or thickener where it is filtered, water washed and emptied from the bottom. The regenerated sodium solution is sent to a mixing tank where sodium chemical compounds (soda ash or caustic soda) and water are added, and directed back to the absorber.

Table 1. Basic operational parameters for lime/limestone systems on utility boilers in US [3]

\begin{tabular}{|c|c|c|c|c|c|}
\hline $\begin{array}{l}\text { Alkaline } \\
\text { mixture }\end{array}$ & Company/plant name & Power, MW & Fly ash control & Sulphur content in coal, \% & L/G ratio, $\mathrm{l} / \mathrm{m}^{3}$ \\
\hline \multirow[t]{3}{*}{ Water + $\mathrm{CaO}$} & $\begin{array}{c}\text { Columbus \& Southern Ohio Electric/ } \\
\text { Conesvill \#5 }\end{array}$ & 411 & $\begin{array}{l}\text { Electrostatic } \\
\text { precipitator }\end{array}$ & 4.7 & 6.7 \\
\hline & Duquesne Light/Elrama & 510 & & 2.2 & 5.3 \\
\hline & $\begin{array}{c}\text { Utah Power \& Light/Hunter \#1, } \\
\text { Hunter } \# 2\end{array}$ & 400 & & 0.6 & 5.7 \\
\hline \multirow[t]{2}{*}{ Water $+\mathrm{CaCO}_{3}$} & $\begin{array}{c}\text { Alabama Electric/Tombigbee \#2, } \\
\text { Tombigbee \#3 }\end{array}$ & 255 & & 1.2 & 9.4 \\
\hline & Commonwealth Edison/Powerton & 450 & & 3.5 & 8.0 \\
\hline
\end{tabular}




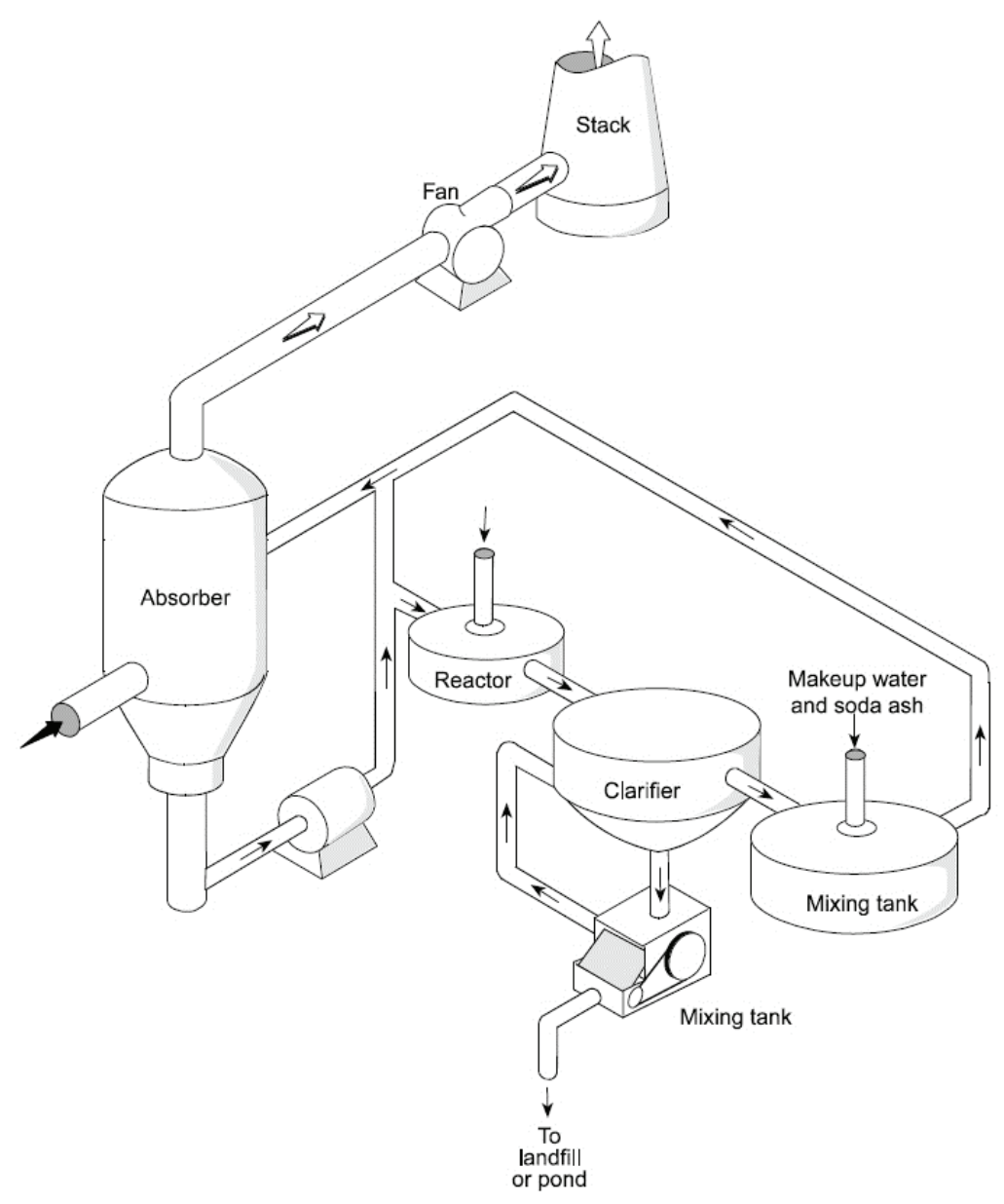

Figure 2. Schematic representation of the dual alkali process [3].

An alkaline solution of sodium is more efficient than lime/limestone solution. The required liquid to gas flow rate ratio (L/G) is much lower compared to the lime/ /limestone process, as can be concluded from Tables 1 and 2. Due to the lower $L / G$ ratio, the process equipment is smaller in size. The process efficiency is about $95 \%$. As a result of good solubility of sulfur oxides in sodium based alkaline solution, problems such as corrosion, erosion and deposit formation inside the equipment and installation are avoided.

Basic operational data for systems using dual alkali FGD process on utility boilers in the United States are given in Table 2 [3].

\section{Amine processes with thermal regeneration}

Processes based on chemical absorption in amines, already have applications for purification of outgoing gases from smelters (with $\mathrm{SO}_{2}$ content higher than 3.5\%). Three aromatic amines, dimethylaniline (DMA), xylidine and toulidine, are commonly used as sorbents. DMA has a lower boiling point than the other two, a higher vapor pressure and its losses during the absorption process are higher. Xylidine is preferable than toulidine, due to its higher boiling point, however it has some undesirable properties. For low $\mathrm{SO}_{2}$ concentrations, a mixture of xylidine and water as sorbent is more suitable, while for higher $\mathrm{SO}_{2}$ concentrations, DMA is more appropriate. The examples of amine processes with thermal regeneration that already found commercial application are Sulphidine process, ASARCO process, Dow process and CANSOLV process. This paper briefly describes the CANSOLV process.

CANSOLV process [6], owned by Cansolv Technologies Incorporated, A Shell Global Solutions Company,

Table 2. Operational data for systems using dual alkali FGD process on utility boilers in the US [3]

\begin{tabular}{lcccc}
\hline Company/plant name & Power, MW & Fly ash control & Sulphur content in coal, \% & L/G ratio, l/m ${ }^{3}$ \\
\hline Central Illinois Public Service/Newton \#1 & 617 & Electrostatic & 2.5 & 1.3 \\
Louisville Gas \& Electric/Cane Run \#6 & 299 & precipitator & 4.8 & 1.3 \\
Southern Indiana Gas \& Electric/A.B. Brown \#1 & 265 & & 3.6 & 1.3 \\
\hline
\end{tabular}


schematically is presented on Figure 3. It has a wide commercial application for purification of outgoing gases in industrial and utility boilers, smelters, refineries and chemical plants. The process has two steps, absorption and amine regeneration step. Flue gases come in contact with the amine solution in countercurrent absorber, and treated gas exits with lower $\mathrm{SO}_{2}$ content. Rich amine solution (with high absorbed $\mathrm{SO}_{2}$ content) flows to the regeneration stage, and comes out as lean amine (with a lower sulfur content). Lean amine solution is regenerated by indirect steam stripping, clean $\mathrm{SO}_{2}$ is set aside, dried and transported to sulfuric acid production unit. Lean amine leaves the regeneration unit and returns to the absorption unit.

CANSOLV process advantages are:

- Final products have its market value (pure $\mathrm{SO}_{2}$, sulfur and sulphuric acid).

- The process does not produce solid waste.

- Low investment and operating costs.

- High flexibility in terms of gas flow rate fluctuations and $\mathrm{SO}_{2}$ concentration in flue gases.

\section{Physical (organic) solvent processes}

Processes with organic solvents are among the most cost-effective and efficient processes for purification of flue gases with high or fluctuating $\mathrm{SO}_{x}$ content. Some organic solvents have excellent selectivity towards $\mathrm{SO}_{2}$, in relation to other flue gas components $\left(\mathrm{N}_{2}, \mathrm{O}_{2}\right.$ and $\mathrm{CO}_{2}$ ). Physical solvent for $\mathrm{SO}_{2}$ removal should have temperature dependent solubility, high selectivity to $\mathrm{SO}_{2}$, high chemical and thermal stability, low vapor pressure, should be environmentally friendly, not harmful to human health and cost effective. Solubility of $\mathrm{SO}_{2}$ increases almost linearly with the increase of the physical solvent partial pressure, while solubility trend in chemical solvents has minimal growth or in some cases near zero.

Advantages of physical solvents in relation to chemical solvents are:

- Cost-effective process (lower energy requirements for solvent regeneration).

- Lack of heat released due to the chemical reactions.

- Useful and commercially valuable product.

Solinox process developed by the Linde AG group, is a practical application of the physical absorption in organic solvents. In United States Solinox process is offered by Lotepro Corporation, using tetraethyleneglycol dimethylether for $\mathrm{SO}_{2}$ removal. Detailed description of the process and operating data from plants purifying flue gas streams that emanate from lead and

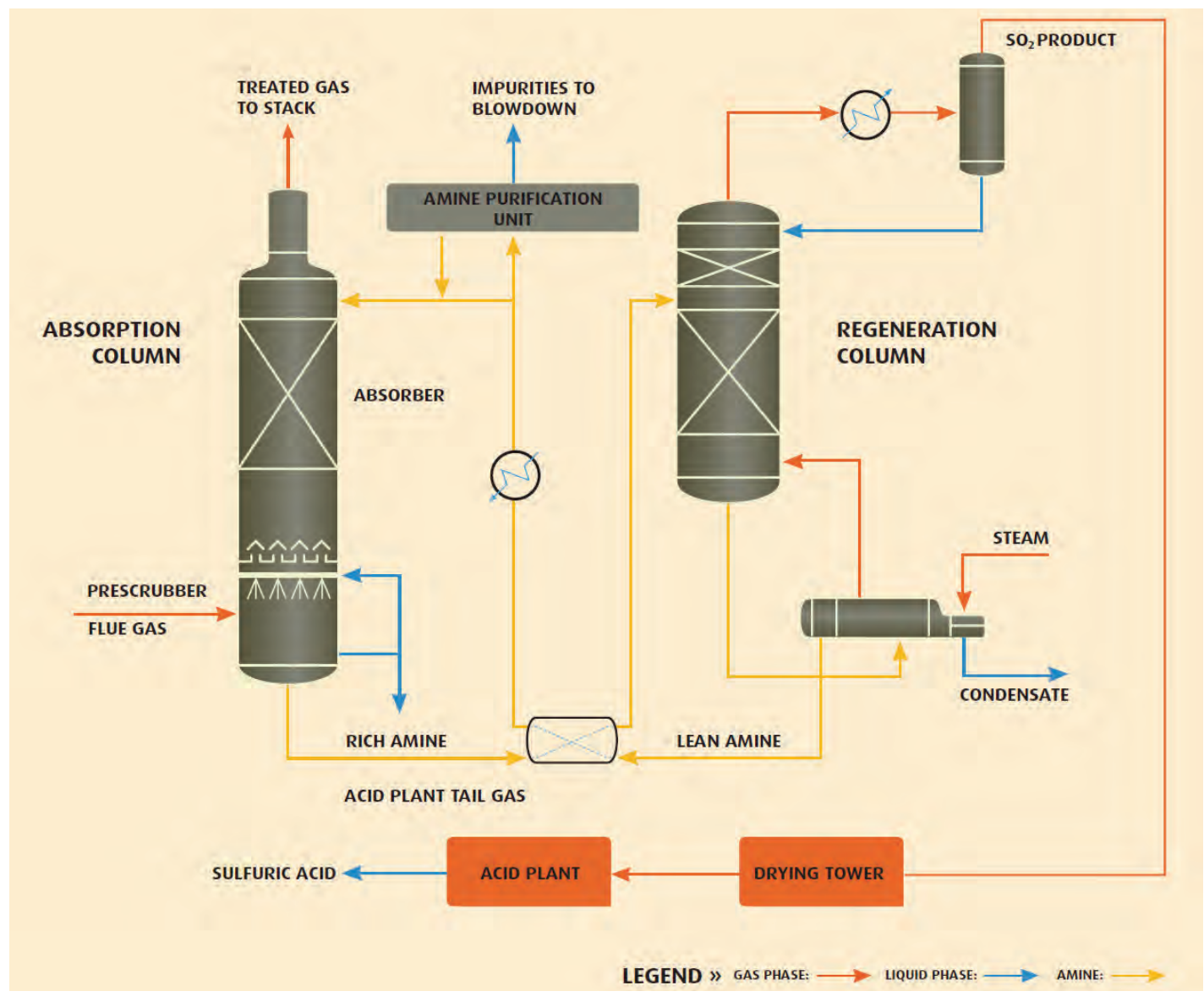

Figure 3. CANSOLV process, schematic representation [6]. 
zinc smelters is given by Sporer [7]. Before entering the absorber, flue gases have to be water washed, in order to lower the flue gas temperature and remove the impurities. The specific feature of this procedure is that it can remove hydrocarbons from outgoing gases, within the requirements for the air pollution control. The obtained removal efficiency for the process is 9599.3\%. Basic Solinox process has absorption and regeneration stage. The absorption stage takes place in countercurrent absorber, while regeneration stage (for separation of $\mathrm{SO}_{2}$ from the solvent) takes place in countercurrent stripper with a reboiler.

However, investigations have shown that selectivity of TEGDME to sulfur dioxide is not satisfactory [8] and NMP as an alternative solvent has been proposed. Industrially, NMP has already been applied is in Lurgi's Purisol process with excellent results in selective desulfurization of flue gasses from oil refineries and power plants.

As an alternative to above mentioned solvents several polymers, including PEG 200 and PEG 400, have been investigated [9]. The main advantages of PEG for desulfurization processes are high solubility and desorption capability for $\mathrm{SO}_{2}$ which lead to lower energy requirements for absorption and regeneration processes.

Ionic liquids have been recently suggested as physical solvents for FGD processes [10-12]. Due to its favorable properties (high stability, low vapor pressure, excellent selectivity towards certain gases and nontoxicity) ionic liquids have found application in various separation processes. The preliminary investigations have shown that ionic liquids could also be used as an alternative to organic solvents in the processes of physical absorption and solvent regeneration.

\section{Determination of thermodynamic and transport properties}

In order to develop an absorption process for flue gases desulfurization and to set a numerical case for computer process simulation or work on equipment design, it is necessarry to have reliable data on chemical, physical and transport properties of potential solvents. In this work the experimental densities and viscosities of five potential solvents for $\mathrm{SO}_{2}$ removal, PEG 200, PEG 400, TEGDME, NMP and DMA, are reported at ten temperatures $(288.15,293.15,298.15$, $303.15,308.15,313.15,318.15,323.15,328.15$ and $333.15 \mathrm{~K})$ and atmospheric pressure.

PEG 200, PEG 400 (99.5 mass\%), NMP (99.0 mass\%), DMA were supplied by Merck and TEGDME $(99.0$ mass\%) by Acros Organics. Chemicals were kept in dark bottles in an inert atmosphere, used without further purification and degassed just before a sample preparation.
Densities, $\rho$, of the pure substances were measured using an Anton Paar DMA 5000 digital vibrating U-tube densimeter (with automatic viscosity correction) having a stated accuracy of $\pm 5 \times 10^{-6} \mathrm{~g} \cdot \mathrm{cm}^{-3}$. The temperature in the cell was regulated to $\pm 0.001 \mathrm{~K}$ with a built in solid-state thermostat. Temperature in the cell was measured by means of two integrated Pt 100 platinum thermometers and temperature stability was better than $\pm 0.002 \mathrm{~K}$. Calibration of the apparatus was performed daily using ambient air and Milipore quality water. The combined expanded uncertainty in the density is within $\pm 2 \times 10^{-5} \mathrm{~g} \cdot \mathrm{cm}^{-3}$ with a 0.95 level of confidence $(k \approx 2)$.

Viscosities, $\eta$, of the pure substances were measured with a digital Anton Paar Stabinger viscometer (model SVM 3000/G2). The instrument contains two measuring cells; one of them is used for measuring the density of the sample. U-tube is filled with the sample liquid and excited to oscillate using magnetic coils. Density measurement is based on the relation between oscillation period and sample density. The other cell, used for dynamic viscosity measurements contains a straight tube filled with sample. The tube rotates at a constant speed. In this tube, centered by the centrifugal force, floats a measuring rotor made of low density material, with a built-in magnet. A rotating magnet in SVM 3000 induces an eddy current field with a speed dependant brake torque. Shortly after the start of the experiment the rotor reaches a constant speed determined by the equilibrium between the viscositydependent driving torque, proportional to the speed difference between the tube and the rotor, and the brake torque caused by eddy currents. The kinematic viscosity is calculated from the measured density and dynamic viscosity. The stated reproducibility of the dynamic viscosity and density measurements is $0.35 \%$ and $5 \times 10^{-4} \mathrm{~g} \cdot \mathrm{cm}^{-3}$ in the temperature interval 288.15 to $333.15 \mathrm{~K}$. The temperature in the cell was regulated to $\pm 0.01 \mathrm{~K}$ with a built in solid-state thermostat. The relative uncertainty in dynamic viscosity measurements was estimated to be within $\pm 0.8 \%$.

\section{RESULTS AND DISCUSSION}

Experimental data of density $(\rho)$ and viscosity $(\eta)$ for pure chemicals PEG 200, PEG 400, TEGDME, NMP and DMA at ten temperatures, 288,15, 293,15, 298,15, $303,15,308,15,313,15,318,15,323,15,328,15$ and $333,15 \mathrm{~K}$, and atmospheric pressure, are presented in Tables 3 and 4.

In Table 5, densities and dynamic viscosities of pure PEG 200, PEG 400, TEGDME, NMP and DMA have been compared with literature values at 298.15 and 303.15 $\mathrm{K}$ [13-24]. The agreement between literature and our experimental values is very good with differences less than $6.5 \times 10^{-4} \mathrm{~g} \cdot \mathrm{cm}^{-3}$ for density measurements and 
Table 3. Measured density values $\left(\rho / \mathrm{g} \cdot \mathrm{cm}^{-3}\right)$ of pure PEG 200, PEG 400, TEGDME, NMP and DMA at atmospheric pressure

\begin{tabular}{lccccc}
\hline$T / K$ & PEG 200 & PEG 400 & TEGDME & NMP & DMA \\
\hline 288.15 & 1.128778 & 1.13009 & 1.01563 & 1.037298 & 0.960062 \\
293.15 & 1.124828 & 1.126001 & 1.010995 & 1.03284 & 0.955975 \\
298.15 & 1.120865 & 1.121905 & 1.006359 & 1.028382 & 0.951878 \\
303.15 & 1.116909 & 1.11802 & 1.001732 & 1.023925 & 0.947778 \\
308.15 & 1.112945 & 1.113711 & 0.997104 & 1.019462 & 0.943669 \\
313.15 & 1.108981 & 1.109622 & 0.992481 & 1.015 & 0.939552 \\
318.15 & 1.105016 & 1.105536 & 0.987859 & 1.010533 & 0.935426 \\
323.15 & 1.101043 & 1.101461 & 0.983234 & 1.006061 & 0.931291 \\
328.15 & 1.097068 & 1.09739 & 0.978613 & 1.001583 & 0.927142 \\
333.15 & 1.093088 & 1.093324 & 0.973989 & 0.997096 & 0.92298 \\
\hline
\end{tabular}

Table 4. Measured viscosity values ( $\eta$ / mPa.s) of pure PEG 200, PEG 400, TEGDME, NMP and DMA at atmospheric pressure

\begin{tabular}{lccccc}
\hline$T / K$ & PEG 200 & PEG 400 & TEGDME & NMP & DMA \\
\hline 288.15 & 86.442 & 161.67 & 4.3415 & 1.9896 & 1.5247 \\
293.15 & 64.815 & 119.54 & 3.8338 & 1.8232 & 1.403 \\
298.15 & 49.724 & 90.582 & 3.3801 & 1.6795 & 1.2965 \\
303.15 & 38.912 & 70.145 & 3.0042 & 1.5546 & 1.2035 \\
308.15 & 31.006 & 55.365 & 2.6913 & 1.4443 & 1.1205 \\
313.15 & 25.102 & 44.463 & 2.4258 & 1.3464 & 1.0462 \\
318.15 & 20.602 & 36.262 & 2.1994 & 1.2593 & 0.97959 \\
323.15 & 17.136 & 29.981 & 2.0063 & 1.1816 & 0.91971 \\
328.15 & 14.424 & 25.097 & 1.8382 & 1.1099 & 0.86528 \\
333.15 & 12.343 & 21.247 & 1.6914 & 1.0427 & 0.81953 \\
\hline
\end{tabular}

Table 5. Densities $\rho$ and dynamic viscosities $\eta$ of pure components at atmospheric pressure

\begin{tabular}{|c|c|c|c|c|c|}
\hline \multirow[t]{2}{*}{ Component } & \multirow[t]{2}{*}{$\mathrm{T} / \mathrm{K}$} & \multicolumn{2}{|c|}{$\rho / \mathrm{g} \cdot \mathrm{cm}^{-3}$} & \multicolumn{2}{|c|}{$\eta / \mathrm{mPa} \cdot \mathrm{s}$} \\
\hline & & Exp. & Lit. & Exp. & Lit. \\
\hline PEG 200 & 298.15 & 1.120865 & 1.12098 [13] & 49.724 & 48.157 [13] \\
\hline \multirow[t]{4}{*}{ PEG 400} & 298.15 & 1.121905 & 1.12249 [13] & 90.582 & $92.797[13]$ \\
\hline & & & $1.12230[14]$ & & \\
\hline & & & 1.1218 [9] & & \\
\hline & & & 1.12162 [15] & & \\
\hline \multirow[t]{4}{*}{ TEGDME } & 298.15 & 1.006359 & 1.0063 [16] & 3.3801 & 3.394 [16] \\
\hline & & & 1.0067 [17] & & $3.313[18]$ \\
\hline & & & 1.0059 [18] & & \\
\hline & & & 1.00653 [19] & & \\
\hline \multirow[t]{2}{*}{ NMP } & 298.15 & 1.028382 & 1.02872 [20] & 1.6795 & $1.656[20]$ \\
\hline & & & 1.0283 [21] & & $1.67[21]$ \\
\hline \multirow[t]{3}{*}{ DMA } & 303.15 & 0.947778 & 0.9484 [22] & 1.2035 & 1.174 [23] \\
\hline & & & $0.948[23]$ & & $1.170[24]$ \\
\hline & & & $0.94833[24]$ & & \\
\hline
\end{tabular}

within $7 \times 10^{-2} \mathrm{mPa} \cdot \mathrm{s}$ for viscosity measurements of less viscous fluids. The differences between experimental and literature values of viscosity are somewhat higher for more viscous fluids but still under $3 \%$ deviation.

Densities of pure components decrease with temperature increase, as expected. Measured density data show linear temperature dependence and can be correlated with linear expression (1):

$\rho=A_{0}+A_{1} T$

With the temperature increase viscosities behave in the same manner as densities, their values decrease 
with temperature increase and can be correlated with polynomial expression (2):

$\eta=B_{0}+B_{1} T+B_{2} T^{2}+B_{3} T^{3}$

Education, Science and Technology Development of the Republic of Serbia and the Faculty of Technology and Metallurgy, University of Belgrade (project No. 172063).

Parameters $A_{0}, A_{1}, B_{0}, B_{1}, B_{2}$ and $B_{3}$ in expressions (1) and (2) are presented in Table 6.

Table 6. Polynomial parameters $A_{p}$ and $B_{p}$ for pure solvents (expressions (1) and (2))

\begin{tabular}{|c|c|c|c|c|}
\hline Property & $A_{0}, B_{0}$ & $A_{1}, B_{1}$ & $B_{2}$ & $B_{3}$ \\
\hline \multicolumn{5}{|c|}{ PEG 200} \\
\hline$\rho / \mathrm{g} \cdot \mathrm{cm}^{-3}$ & 1.3573 & -0.0008 & - & - \\
\hline$\eta / \mathrm{mPa} \mathrm{s}$ & 33739 & -310.01 & 0.9516 & -0.001 \\
\hline \multicolumn{5}{|c|}{ PEG 400} \\
\hline$\rho / \mathrm{g} \cdot \mathrm{cm}^{-3}$ & 1.3656 & -0.0008 & - & - \\
\hline$\eta / \mathrm{mPa} \mathrm{s}$ & 68033 & -626.54 & 1.9271 & -0.002 \\
\hline \multicolumn{5}{|c|}{ TEGDME } \\
\hline$\rho / \mathrm{g} \cdot \mathrm{cm}^{-3}$ & 1.2822 & -0.0009 & - & - \\
\hline$\eta / \mathrm{mPa} \mathrm{s}$ & 440.97 & -3.8412 & 0.0113 & $-110^{-5}$ \\
\hline \multicolumn{5}{|c|}{ NMP } \\
\hline$\rho / \mathrm{g} \cdot \mathrm{cm}^{-3}$ & 1.2947 & -0.0009 & - & - \\
\hline$\eta / \mathrm{mPa} s$ & 125.22 & -1.0819 & 0.0032 & $-310^{-6}$ \\
\hline \multicolumn{5}{|c|}{ DMA } \\
\hline$\rho / \mathrm{g} \cdot \mathrm{cm}^{-3}$ & 1.1975 & -0.0008 & - & - \\
\hline$\eta / \mathrm{mPa} s$ & 72.575 & -0.6057 & 0.0017 & $-1.710^{-6}$ \\
\hline
\end{tabular}

\section{CONCLUSION}

In the years to come, Republic of Serbia will be faced with the need and obligations to reduce emissions of greenhouse gases, including sulfur oxides. In view of this fact, particular attention has to be focused on emissions from major polluters - the stationary power plants.

In this paper, review of wet flue gas desulphurization technologies has been presented. The most common technology for flue gas desulfurization is wet lime/limestone process. With development of flue gas desulphurization technology, wet procedures with solvent regeneration attract more attention, because of their advantages, in terms of efficiency, solvent use and environmental impact. Among regenerative procedures the most widespread are dual alkali process and processes based on absorption in amines or absorption in organic solvents.

The transport properties of potential solvents for FGD processes are of great importance for computer simulation and equipment design. Thermophysical and transport properties (density and viscosity) of pure solvents, PEG 200, PEG 400, TEGDME, NMP and DMA have been measured and presented in the paper.

\section{Acknowledgment}

The authors gratefully acknowledge the financial support received from the Research Fund of Ministry of

\section{REFERENCES}

[1] Sulfur Dioxide, EPA - United States Environmental Protection Agency, (http://www.epa.gov/air/sulfurdioxide/).

[2] European Commission, Climate Action, EU greenhouse gas emmissions and targets, (http://ec.europa.eu/ /clima/policies/g-gas/index_en.htm).

[3] Flue Gas Desulfurization (Acid Gas Removal) Systems, Lesson 9, United States Environmental Protection Agency (www.epa.gov).

[4] R.K. Srivastava, W. Jozewicz, C. Singer, $\mathrm{SO}_{2}$ Scrubbing Technologies: A Review, Environ. Prog. 20(4) (2001) 219-228.

[5] Wet Gas Desulfurization (FGD) Systems, Advanced Technology For Maximum $\mathrm{SO}_{2}$ Removal, Babcock \& Wilcox Power Generation Group (www.babcock.com).

[6] Cansolv Technologies Incorporated, A Shell Global Solutions Company, State of the Art Gas Absorption Solutions (www.cansolv.com).

[7] J. Sporer, The Linde Solinox Process: Gypsum-free fluegas desulphurization, Gas Separ. Purif. 6(3) (1992) 133$-140$.

[8] M.H.H. van Dam, A.S. Lamine, D. Roizard, P. Lochon, C. Roizard, Selective Sulfur Dioxide Removal Using Organic Solvents, Ind. Eng. Chem. Res. 36 (1997) 4628-4637.

[9] F. Han, J. Zhang, G. Chen, X. Wei, Density, Viscosity and Excess Properties for Aqueous Poly(ethylene glycol) Solutions from (298.15 to 323.15) K, J. Chem. Eng. Data 53 (2008) 2598-2601. 
[10] X.L. Yuan, S.J. Zhang, X.M. Lu, Hydroxyl Ammonium lonic Liquids: Synthesis, Properties, and Solubility of $\mathrm{SO}_{2}$, J. Chem. Eng. Data 52(2) (2007) 596-599.

[11] K.Y. Lee, G.T. Gong, K.H. Song, H. Kim, K.D. Jung, C.S. Kim, Use of Ionic Liquids as absorbents to separate $\mathrm{SO}_{2}$ in $\mathrm{SO}_{2} / \mathrm{O}_{2}$ in thermochemical processes to produce hydrogen, Int. J. Hydrogen Energy 33(21) (2008) 6031-6036.

[12] J. Huang, A. Riisager, P. Wasserscheid, R. Fehrmann, Reversible physical absorption of $\mathrm{SO}_{2}$ by ionic liquids, Chem. Commun. (2006) 4027-4029.

[13] S. Ottani, D. Vitalini, F. Comelli, C. Castellari, Densities, Viscosities, and Refractive Indices of Poly(ethylene glycol) 200 and $400+$ Cyclic Ethers at $303.15 \mathrm{~K}$, J. Chem. Eng. Data 47 (2002) 1197-1204.

[14] E.A. Mueller, P. Rasmussen, Densities and excess volumes in aqueous poly(ethylene glycol) solutions, J. Chem. Eng. Data 36 (1991) 214-217.

[15] C. Aucouturier, G. Roux-Desgrenges, A.H. Roux, Excess Molar Volumes and Excess Molar Heat Capacities of Poly (ethylene glycols)+Water at Temperatures between $T=$ $278 \mathrm{~K}$ and $T=328 \mathrm{~K}$, J. Chem. Thermodyn. 31 (1999) 289-300.

[16] A. Pal, G. Dass, A. Kumar, Excess Molar Volumes, Viscosities, and Refractive Indices of Tetraethylene Glycol Dimethyl Ether + Dimethyl Carbonate, + Diethyl Carbonate and + Propylene Carbonate at 298.15 K, J. Chem. Eng. Data 44 (1999) 2-5.

[17] J.N. Real, T.P. Iglesias, S.M. Pereira, M.A. Rivas, Analysis of temperature dependence of some physical properties of (n-nonane + tetraethylene glycol dimethyl ether), J. Chem. Thermodyn. 34 (2002) 1029-1043.
[18] M.E. Ferreyra de Ruiz Holgado, C.R. de Schaefer, E.L. Arancibia, Densities and Viscosities of Binary Mixtures of Polyethylene Glycol 350 Monomethyl Ether with $n$-Butanol and $n$-Pentanol and Tetraethylene Glycol Dimethyl Ethers with $n$-Propanol, $n$-Butanol and $n$-Pentanol from 278.15 K to 318.15 K, J. Chem.Eng. Data 47 (2002) 144$-148$.

[19] F.J. Carmona, F.J. Arroyo, I.D. de la Fuente, J.A. Gonzales, J.C. Cobos, Excess Molar Volumes of Methanol or Ethanol $+n$-Polyethers at $298.15 \mathrm{~K}$, Can. J. Chem. 77 (1999) 1608-1616.

[20] A. Henni, J.J. Hromek, P. Tontiwachwuthikul, A. Chakma, A. Volumetric Properties and Viscosities for Aqueous $\mathrm{N}$-Methyl-2-pyrrolidone Solutions from $25^{\circ} \mathrm{C}$ to $70{ }^{\circ} \mathrm{C}$, J. Chem. Eng. Data ${ }^{\circ} \mathrm{C}$ (2004) 231-234.

[21] D.D. McDonald, D. Dunay, G. Manlon, J.B. Hyne, Properties of the $\mathrm{N}$-methyl-2-pyrrolidinone-water system, Can. J. Chem. Eng. 49 (1971) 420-423.

[22] V. Pandiyan, S.L. Oswal, P. Vasantharani, Thermodynamic and acoustic properties of binary mixtures of ethers. IV. Diisopropyl ether or oxolane with $\mathrm{N}, \mathrm{N}$-dimethylaniline or $\mathrm{N}, \mathrm{N}$-diethylaniline at $303.15,313.15$ and 323.15 K, Termochim. Acta 518 (2011) 36-46.

[23] M. Kondaiah, D. Sravana Kumar, K. Sreekanth, D. Krishna Rao, Densities and Viscosities of Binary Mixtures of Propanoic Acid with $N, N$-Dimethylaniline and $N, N$-Diethylaniline at $T=(303.15,313.15$, and 323.15) $\mathrm{K}$, J. Chem. Eng. Data 57 (2012) 352-357.

[24] A.G. Oskoei, N. Safaei, J. Ghasemi, Densities and Viscosities for Binary and Ternary Mixtures of 1,4-Dioxane + 1-Hexanol $+N, N$-Dimethylaniline from $T=(283.15$ to 343.15) K, J. Chem. Eng. Data 53 (2008) 343-349. 


\section{IZVOD}

\section{PREGLED MOKRIH POSTUPAKA ZA ODSUMPORAVANJE DIMNIH GASOVA I ODREĐIVANJE TERMOFIZIČKIH SVOJSTAVA NJIMA ODGOVARAJUĆIH RASTVARAČA}

Nikola Živković ${ }^{1}$, Slobodan Šerbanović², Emila Živković², Mirjana Kijevčanin ${ }^{2}$, Predrag Stefanović ${ }^{1}$

${ }^{1}$ Institut za Nuklearne Nauke "Vinča", Univerzitet u Beogradu, Laboratorija za termotehniku i energetiku, p. pr. 522, 11001 Beograd,Srbija

${ }^{2}$ Tehnološko-metalurški fakultet, Univerzitet u Beogradu, Karnegijeva 4, 11120 Beograd, Srbija

(Naučni rad)

Za ublažavanje klimatskih promena, neophodno je izvršiti smanjenje emisija gasova sa efektom staklene bašte među koje spadaju i sumporni oksidi iz stacionarnih termoenergetskih postrojenja. Ublažavanje promena je uslovljeno zakonskim okvirom Evropske Unije. Ispunjenje ove obaveze je i pred Republikom Srbijom u narednim godinama. $\mathrm{S}$ obzirom na prioritete i aktuelnost navedene problematike, u radu je data kategorizacija mokrih postupaka za uklanjanje sumpornih oksida iz dimnih gasova iz termoelektrana i prikazane su karakteristike odgovarajućih solvenata za regenerativne postupke. Opisan je u praksi najzastupljeniji mokri krečni postupak. Predstavljeni su postupci sa termalnom regeneracijom solventa zasnovani na hemijskoj ili fizičkoj apsorpciji, koji u poslednje vreme imaju sve veći značaj. Prikazani su rezultati eksperimentalnog određivanja termofizičkih svojstva komercijalno primenjenih i alternativnih solvenata, koja su od primarnog značaja za projektovanje opreme i optimizaciju procesa. Izmerene vrednosti gustine i viskoznosti čistih rastvarača, polietilenglikol 200 i 400 (PEG 200 i PEG 400), tetraetilenglikola-dimetil-etar (TEGDME), N-metil-2-pirolidona (NMP) i dimetilanilina (DMA), na atmosferskom pritisku, predstvljene su u funkciji temperature.

Ključne reči: Uklanjanje sumpornih oksida • Dimni gasovi • Termoelektrana • Gustina • Viskoznost • Klimatske promene 